Molecular Biology of Prostate Cancer 



\section{Molecular Biology of Prostate Cancer}

Editors

M. Wirth · J. E. Altwein - B. Schmitz-Dräger · S. Kuptz

Walter de Gruyter

Berlin · New York 1998 
Prof. Dr. M. Wirth

Universitätsklinikum Dresden

Klinik für Urologie

Fetscherstr. 74

01307 Dresden

Germany

Prof. Dr. J. E. Altwein

Krankenhaus der Barmherzigen Brüder

Klinik für Urologie

Romanstr. 93

80639 München

Germany
Prof. Dr. B. Schmitz-Dräger

Heinrich-Heine-Universität Düsseldorf

Klinik für Urologie

Moorenstr. 5

40225 Düsseldorf

Germany

Dr. S. Kuptz

Zeneca GmbH

Forschung Onkologie/Endokrinologie

Otto-Hahn-Straße

68723 Plankstadt

Germany

Die Deutsche Bibliothek - Cataloging-in-Publication-Data

Molecular biology of prostate cancer / ed. M. Wirth ... . Berlin ;

New York : de Gruyter, 1998

ISBN 3-11-016159-1

(C) Copyright 1998 by Walter de Gruyter GmbH \& Co., D-10785 Berlin.

All rights reserved, including those of translation into foreign languages. No part of this book may be reproduced in any form - by photoprint, microfilm or any other means nor transmitted nor translated into a machine language without written permission from the publisher.

Medical science is constantly developing. Research and clinical experience expand our knowledge, especially with regard to treatment and medication.

For dosages and applications mentioned in this work, the reader may rely on the authors, editors and publisher having taken great pains to ensure that these indications reflect the standard of knowledge at the time this work was completed.

Nevertheless, all users are requested to check the package leaflet of the medication, in order to determine for themselves whether the recommendations given for the dosages or the likely contraindications differ from those given in this book. This is especially true for medication which is seldom used or has recently been put on the market and for medication whose application has been restricted by the German Ministry of Health. The quotation of registered names, trade names, trade marks etc. in this copy does not imply, even in the absence of a specific statement that such names are exempt from laws and regulations protecting trade marks etc. and therefore free for general use.

Reproductions, typesetting and printing: Arthur Collignon $\mathrm{GmbH}$, Berlin - Binding: Lüderitz \& Bauer GmbH, Berlin - Cover design: Rudolf Hübler, Berlin

Printed in Germany 